\title{
Nature and essential characteristics of classical rationality
}

\author{
V.S. Levytskyy
}

Ukrainian Institute of Strategies of Global Development and Adaptation, 6, Rond-point Schuman, 1040, Brussel, Belgium

For citation: Levytskyy V.S. Nature and essential characteristics of classical rationality. Vestnik of Saint Petersburg University. Philosophy and Conflict Studies, 2019, vol. 35, issue 3, pp. 430-446. https://doi.org/10.21638/spbu17.2019.304

The $20^{\text {th }}$ century began under the sign of deconstruction of the classical comprehension of substantiality of history, culture and mind. It turned out that each culture has its unique worldview universals and a conclusion has been made that there is a principal difference between classical and modern cultural worlds, and in the rationalities characteristic to them. In the article, based on V.Stepin's conception of scientific rationality, the essential characteristics of the classical mind, which possess heuristic potentials when comparing pre-modern and modern rationality, are explicated. In particular, the ontologism of the pre-modern mind has been distinguished and substantiated based on historical and philosophical material - rootedness in being, only partially related to man; its hierarchy is the dependence of cognitive possibilities on the ontological level of the entities opening to the mind; and the transcendence is the fundamental incomprehensibility of the bases and "guarantors" of the mind and the world for the mind itself. Within the framework of the classical mind, archetypical principles of Western rationality were formulated as such, some of which, after the secularization of medieval culture, became the principle of organizing secular social reality, which ultimately led to the emergence of a new social reality, later called Modernism.

Keywords: mind, rationality, modernity, ontology, hierarchy, transcendence.

Every person is surely confident in his ability to use his/her own mind. Rationality for some time has generally become synonymous with civilization. At about the same time (the second half of the nineteenth century), doubts about the cultural invariance of rationality also began to creep in. Practical use of mind has become dependent on a particular cultural tradition. Inclusion in this tradition makes us confident in the adequate operation of the mind: rationality becomes a part of the norm. In this case, in an ordinary situation, the question of the basis of one's own, and especially cultural mind never arises.

The situation changes when "anomalies" appear in the discourse (using Kuhn's terminology), in the form of representatives of other cultures, or the heritage of other eras. In such situations comes an awareness of the particularity of mind of one's own culture even if a person believes infallibly in the superiority of his own rationality, he cannot but feel the otherness of his opponent's rationality leading to the specified stress.

It should be noted that the twentieth century began and went under the sign of the deconstruction of Hegel's (originally Christian) understanding of the substantiality of history, culture, and mind. Neo-Kantians of the Marburg school showed that the transcendental subject is culturally determined, Wittgenstein linked rationality with depth grammar, Heidegger combined linguistic and ontological imperatives, Foucault put meaning in

(c) Санкт-Петербургский государственный университет, 2019 
discourse. In the second half of the last century, and especially after the linguistic turn, the particularity of individual cultural worlds became philosophy's commonplace. It turned out that each culture has its own unique worldview universals, if we use the terminology of Stepin. Thus, this philosophical tradition comes to the necessary conclusion regarding the fundamental difference between the classical and modern cultural worlds, and their rationalities accordingly.

At the same time, many authors (Losev, Averintsev, Borodai, Sidash, Heidegger, Maritain, Gilson, Swiezawski) made the specifics of the classical period the subject of their research. They were able to identify its characteristic features and indicate some of its universal features. Against the background of these explications regarding the classical mind, a different architectonics of its modern heir is well seen.

The subject of this article is formed at the intersection of these two methodologies. On the one hand, aimed at clarifying the unique for the premodern mind and at the same time its unique foundations, on the other hand - establishing their connection with those of its structures (principles) that the Modern Mind inherited.

Before moving on to the main subject of this research, it is vital to have a clear understanding of the main terminology. We are talking about such definitions as "mind", "intelligence", "reason". On the one hand, it seems that there is no problem here, and the use of these terms is quite self-evident - we use them on a daily basis and, without the slightest difficulty, move from one to the other, often using them as synonymous. On the other hand, if we talk about the scientific problem of demarcating the meanings of these terms, then it is very difficult to reach a certain level of generalizations (for example, cultural), because even within the same cultural integrity, different authors can use these terms vari$\mathrm{ably}^{1}$. Therefore, the following reflection is not an attempt to linguistic, but rather to semantic classification.

The thing the ancient Greeks called Siávora (dianoia), and with which they associated discursive thinking, reasoning that is passing from one sensual subject to another, in Latin, became the ratio, and the most adequate analogue of it in Russian can be considered as reason ${ }^{2}$. In the Russian-speaking tradition, the more well-established translation of the Latin "ratio" is "mind", but if you follow the meaning, the more appropriate translation is still to recognize the "reason", especially when it comes to medieval philosophy. Moreover, such a reading is quite admitted by Latin dictionaries ${ }^{3}$.

Greek voũc (noûs), corresponds to the Latin intellectus and the Russian "mind", less often the "intellect" is used (due to the greater everydayness of the meaning of the latter).

${ }^{1}$ A good example in this case is the work of Thomas Aquinas and Duns Scotus. Speaking of higher cognitive ability, which the Greeks called voũc (mind), Thomas uses the term "intellectus", which is translated into Russian with the term "mind" (sometimes intellect). In the same case, Duns Scotus along with "intellectus" and "ratio" uses the definition of "mentis", which is generally characteristic of the Augustinian tradition of the Franciscans ("mens" is the term of St. Augustine to mean "reason"). See, respectively [1;2].

${ }^{2}$ Plato, at the end of the sixth book of the dialogue "The Republic", gave an excellent hermeneutics of the separation of mind and reason. See "State" $511 \mathrm{de}$.

${ }^{3}$ See, for example, the interpretation of this term in the Large Latin-Russian Dictionary.

${ }^{4}$ Such a synonymous series is confirmed by the article in the European Dictionary of Philosophy, which deals with the interpretation of the term "Intellectus". This article especially draws attention to the codification in the period of the scholasticism of the repathetical understanding of "intellectus", as "voũ $\varsigma$ ", on

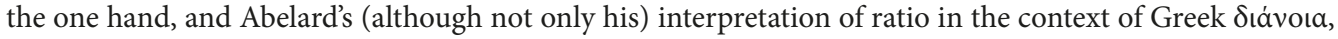
rational discursive activity on the other. See [3, p. 96-107]. At the same time, for example, Losev in the volume "Aristotle and the Late Classics" of "The History of Ancient Aesthetics" citing an excerpt from "On 
In philosophical literature, it is customary to use "reason" ${ }^{5}$ rather than "mind" if it is not a question of special studies dedicated to, for example, the philosophy of Aristotle, Plotinus or Proclus. This is the highest intellectual ability of a person, the main characteristic of which is associated with the intuitive grasp of truth as a whole - this is not thinking, but knowledge, vision, contemplation ${ }^{6}$. This position typical of ancient philosophy was well understood by the Church Fathers, so Anthony the Great wrote: "The body's organ of vision is the eye, the soul's organ of view is the mind... The soul that lacks a good mind and a good life is blind... The eye sees the visible, and the mind perceives the invisible. The Godloving mind is the light of the soul. Those who have a God-loving mind are enlightened by the heart and see God with the mind"' (cit. by: [6]).

It should be said that even though the use of the category "mind" in modern philosophical discourse will be perceived rather as a kind of rudiment, the archetype of the dichotomous division of cognitive ability remains unchanged throughout the history of the development of Western philosophy. Even Kant, with the revolution he had accomplished, could not do anything with the structure of the Greek-scholastic heritage. The only thing he managed to do was to add new content to these categories, although this Copernican revolution, which is crucial for the West, can be organically written into the history of the development of European nominalism, showing that this revolution is only a radicalization of the existing tradition.

Having some terminological subtleties clarified, we can go directly to the foundations of the classical mind, which constitute its being. Despite the fact that the subject of further consideration will be the pre-modern classical mind, scientific research must take into account the transformations of the rationality that has occurred and resulted in the birth of scientific rationality itself. Speaking of various types of scientific rationality that underlie classical, non-classical and post-non-classical science, Stepin, on the basis of the structure of the foundations of science proposed by him, identifies three criteria that determine them: 1) the peculiarity of the systemic organization of objects that make up the subject of scientific research, 2) instrumental and methodological features of cognitive activity, 3) features of subject-object relations between the scientist and the subject of science. The first criterion, by its nature, is ontological and reflects the scientific community's ideas about the world under study, the second, epistemological, fixes the most adequate

the Soul" of Aristotle, indicates that "the translator instead of the Greek" mind "puts the Russian" mind " which is corresponding, rather not Greek noûs, but Greek dianoia [4, p. 78]. Although in the volume "Sophists. Socrates. Plato", in the part of Plato's thinking on thinking that is devoted to analysis, uses" mind "and" reason "as interchangeable concepts [5, p. 451]. However, this remark of the Russian-Soviet scholar is intended, rather, to emphasize the difference between the understanding of the "mind" in antiquity (which is sometimes translated as intelligence) and the "mind" of modern philosophy.

${ }^{5}$ However, despite the fact that "reason" is a more commonly used term in philosophical literature, the Russian language still captured the essential characteristic of this type of knowledge in the word speculation (умозрение), which indicates intelligent vision (умное зрение), when by analogy with the eye, the mind seizes the intelligible image as a whole.

${ }^{6}$ Analyzing Plotinus's legacy, Averintsev summarized the difference between reason and mind (intelligence) very succinctly: "The founder of Neo-Platonism, Plotinus contrasts the alphabet with the Egyptian hieroglyph: the sign system of the alphabet, like the discursive work of reason, parses the word into" elements "and then mechanically assembles it from them, but more noble is the symbolism of the hieroglyph offering our "vision," the intuition of our mind is a holistic and indecomposable eidos» [7, p. 87].

7 Archpriest Leonov gives a good difference analysis for the difference between "mind", "intelligence" and "reason" in patristic literature, showing that the price for sin was the "slide" from the contemplative mind to the reasoning mind [6]. 
ways of the researcher's cognitive interaction with reality, the third characterizes the scientific community's ideas about the goals and possibilities of the scientific mind as such. Taking into account the deserved authority of Viacheslav Stepin's concept received in the philosophy of science, it seems justified to extend it to a wider cultural context and try to characterize the classical mind on the basis of ontological, epistemological and subjectobject criteria.

From the point of view of the "ontological" criterion, the most stable feature of the world that opened up to the classical mind as an object of its comprehension, distinguishing it from later views (for example, the mechanistic picture of the world of classical science) is its religious and mythological coloring. The world did not appear in front of a man in the form of a "picture", but absorbed him as a necessary element of the Cosmos or Creation. The mind itself was not considered as an attribute of "humanity", but was a structural element of the existing. From the point of view of the "epistemological" criterion, the classical mind, in accordance with the ontological hierarchy of the being, should be characterized as principally hierarchical. If we talk about the third criterion of rationality when characterizing the type of subject-object relations, then the classical mind, in accordance with the features of the basic for ancient antiquity Platonic ontology and, moreover, Christian ontology, is distinguished by the fundamental transcendence of its foundations.

In this case, classical mind is characterized by ontologism - rootedness in being, only partially connected with a person; hierarchism - the dependence of cognitive possibilities on the ontological level of entities that are being opened to the mind and transcendence - the fundamental incomprehensibility of the foundations of mind and the world for the mind itself.

\section{Ontologism of the classical mind}

The mind (intelligence) for classical discourse is always a part of ontology, an essential entity in the hierarchy of the degrees of being. Hence, human cognitive activity is not a function of thinking (brain), but an existential cosmic (theological) process: knowledge (as, indeed, the sphere of practical reason), is determined ontologically, not by anthropology in the broad sense, as it is in the case of the modern mind. The idea of unity of thinking and being, starting from at least the philosophy of the Eleatics, runs like a red thread through all antiquity: you can (and need to) know only what dwells forever and never changes - everything sensual is just an illusion that needs to be avoided. "One and the same is a thought and that to which the thought strives", said Parmenides, "since one cannot find thoughts without being, in which this thought is realized. After all, there is and there will be nothing else other than being, since fate has tied being with completeness in itself and stillness" [8]. Thinking is a true being - Mind is not a means (tool) of knowledge, but being itself, which thinks of itself. As Losev believed, Plato was the first who gave thinking, substantiality - Mind, in his philosophy, became a separate substance.

The ontological nature of the foundations of reason in the works of Plato is not difficult to find. Here it can be said, firstly, that the structure of man completely repeats the structure of the cosmos: there is a body in which the soul dwells, and the mind is placed in it. This is the old idea of the coincidence of the microcosm with the macrocosm. Losev, analyzing Plato's "Timaeus", writes: "The body, mind and soul are equal components of both God and man (30b, 70a ff.). We find a striking correspondence between the structure 
of the cosmos' soul (35a cl.) and the properties of the human soul (43 and 37a)... The human mind of Plato functions in the same way as the mind of the cosmos (43de-44a and 41d)" [5, p.621]. Secondly, we can describe a more significant point, which allows us to speak about Plato's ontologism. The Demiurge himself, the creator of the world, is Mind. In Timaeus, Plato writes: "Everything said so far, with a few exceptions, pointed to phenomena created by the power of reason" 8 (48a) [9, p. 419], and the Russian explorer of the creativity of the Greek thinker on this basis asserts: "The text cited suggests that Plato identified the demiurge with the mind..." [10, p.52-53]. The author of the classical translations (which in some way became canonical) of Plato's texts into Russian Vasiliy Karpov wrote in this context: "Plato understood God as the highest and absolute mind, free and independent of anything outside, - from which everything that exists, got its start" [9, p. 354-355]. The demiurge creates the world by looking at ideas ${ }^{9}-$ eternal patterns ${ }^{10}$ that set the archetype and the human knowledge of truth. Avoiding the changeable, the human mind should focus on finding the eternal identities of true eidos. Thus, true knowledge for Plato lies in the contemplation of the world of ideas, genuine being, the human mind imitates the universal mind, which observes the eidos within itself. "The whole point is," Losev writes, "that thinking, according to Plato, is primarily ontological..." [5, p. 457]. In this way, a balance of being and thinking is established and, perhaps, for the first time, the concept of self-thinking thought is developed. Climbing up the steps of thinking, one gradually gets closer to the true being, respectively, the truth is not a search for authenticity, but a contemplation (reunion) of being itself ${ }^{11}$.

From the ingenious intuitions of Plato, Aristotle developed an explicit teaching about the cosmic Mind ${ }^{12}$. This is the topic, to which he dedicated the XII book of his "Metaphysics". In it, Stagirite develops the concept of God-Mind, perhaps, for many centuries ahead, defining reflection strategies on this topic. This divine Mind is motionless, unchanging, eternally relevant, having itself as a goal, thinking itself. "Thus," Aristotle writes about this Mind, "it is clear that the mind thinks the most divine and the most worthy and is not a subject to change, because its change would be for the worse, and this is already some movement. So, firstly, if the mind is not an activity of thinking, but an ability for it, then naturally the continuity of thinking would be difficult for it. Secondly, it is clear that something else would exist, more worthy than the mind, namely, comprehended by thought ... Therefore, the mind thinks of itself if it is superior and its thinking is thinking

${ }^{8}$ It should be said that there are more emblematic translations of this passage, for example, Boroday in the monograph "The Birth of a Philosophical Concept. God and matter in the dialogues of Plato "translates it as follows": Everything we have said so far, with minor exceptions, described things as they were created by the Demiurge's mind" [10, p. 52].

${ }^{9}$ See, for example, Timaeus 30b-31b, 39e.

10 This moment fundamentally distinguishes the creationist theories of Plato and the Bible - unlike the Plato texts, in Christianity God creates the world from nothing.

${ }^{11}$ It is appropriate to recall the concept of Martin Heidegger, who understood the truth of the times of antiquity as $\dot{\alpha} \lambda \imath \theta \varepsilon \_\alpha$ (aletheia) and opposed it to modernity of authenticity, and considered the entire history of the West as oblivion of existence. See more: [12;13].

${ }^{12}$ Losev, for example, justifies a position opposite to a long tradition that comes at least from the Middle Ages, he insists that Aristotle did not criticize and deny Plato's teachings, but developed and perfected - it is completely wrong to understand Aristotle as an antagonist of Plato - he is the successor of his work. Thus, in the context of the theory of the Mind, Losev writes: "In Plato's work the Mind consists of ideas, and in Aristotle's work the Mind consists of ideas in exactly the same way; and both of these Minds, both philosophers have as the same eternal and actual cosmic or rather supra-cosmic Mind" [4, p. 43]. 
about thinking" [11, p.371]. Here it is important to note a few things. Firstly, the mind is a part of the structure of being, even more so, the very being. Secondly, a distinction is made between potential and actual reason, which from this time will steadily go down in the history of this question, and will be especially important for medieval philosophy. Thirdly, self-reflection (knowledge of oneself knowing and at the same time awareness of the coincidence between subject and object, if we are using the language of German classical philosophy) is substantiated as the highest form of activity.

By virtue of the existential dependence of man on this Mind and actions in his likeness, the private subjective mind can reason only because there is this eternally actual Mind. This was amply summarized by Losev, pointing to the ontological understanding of thinking in antiquity: "The potential mind, from its (Aristotle's. - V.L.) point of view, can exist only when there is an actual energy mind. The material immersion of the mind has for itself the condition of its ability to have an immaterial mind. The passive mind, burdened with sensual representations, is possible only when there is an actual mind without any material sensuality. And, finally, the individual and subjective mind of a person has as a condition of its possibility for the existence of the universal and objective Mind" [4, p. 44-45].

The most complete form of this concept of the divine Mind was acquired in Plotinus' philosophy (if you agree with the opinion that Proclus simply developed the Plotinus' doctrine, without adding anything substantially new to it), which in this context is closer, oddly enough, to Aristotle than to Plato ${ }^{13}$. The founder of Neo-Platonism develops and substantiates with the new power the classical ancient idea of the unity of being and thinking ("Parmenides - before Plato - taught the same thing, because he connected the essence and the Mind in the identity, believing that things are not sensible things, saying that "to think and to be is the same" [14, p. 22]), and develops the Platonic-Aristotelian conception of the self-thinking thought as the essence of Mind ${ }^{14}$ : Thus, the Mind and the intelligible are one thing, it is the Being, and the first Being, it is the first Mind that has things truly or, rather, is identical with them ${ }^{15}$ " [14, p. 70].

Plotinus not only reduces everything to one reason, insisting that "all things exist thanks to the One" (En VI. 9.1), but he develops a complete cosmology that implies a strict hierarchy, supported by the emanation of the One. The Cosmic Mind turns out to be the ultimate essence about which the cataphatic discourse is possible, which, in turn, makes possible any thinking of private minds. In the Fifth Ennead, Plotinus writes: "And all things, attaining perfection, give birth; The One always gives birth perfectly and forever; while the creatures are smaller than himself. What then should be said about the absolut perfect? Nothing can happen from Him, except the following after Him in greatness. The mind is this next in greatness, and second; because the Mind sees the One and needs only Him; The One does not need Mind; born of the Superior, there can only be Mind - Mind that surpasses all things, because other things come after Mind, for example, the Soul, which is the Logos of Mind and one of His energies, since Mind is the Mind of the One"

${ }^{13}$ See the position of Losev on this subject, which then became widely replicated in many studies on the Plotinus' philosophy [15].

14 The same idea is concisely formulated by Proclus, the finisher of the neo-Platonic tradition, in his treatise "The Fundamentals of Theology": "167. Every mind thinks of itself, but the first mind is only of itself; and in it the mind and the intelligible are one in number" [16].

${ }^{15}$ Enneads contain dozens of arguments on this topic in this context. See, for example, En V.3.5; 4.2. 
$[14$, p. 18]. For antiquity, to be rational and to exist generally means to be part of the hierarchy of beings. The mind is a part of being, being itself, and therefore thinking (rational action) is not a function of the body, but an approach of the soul to the true being itself.

During the period of the Middle Ages, not only was this maxim not abandoned, but developed even more on new cultural soil. Here you can recall the work and saint Augustine, and the treatises of Pseudo-Dionysius the Areopagite, and the heritage of St. Thomas Aquinas and others. Medieval thought absorbed many ancient developments: from the categorical apparatus and methodology to the Neo-Platonic trinity and the doctrine of entelechy. The concept of God as the supreme Mind (the second hypostasis is completely analogous to the ancient tradition), already formulated in the first lines of the Gospel of John: "In the beginning was the Word, and the Word was with God, and the Word was God" (John 1: 1) which, on the one hand, canonizes the idea of God-Mind, on the other, introduces a specifically Christian understanding of this Being - from the faceless abstract world principle of antiquity, it turns into the personified personality of God the Son.

In the philosophical language of high scholasticism, it began to sound as follows: "Thus, we know the mind, which refers to the universal being as an act of all being, and this is the divine mind, which is the essence of God and in which everything that exists from the very beginning and virtually is preexisting as in its reason" [17, p. 92]. This excerpt from the "Summa Theologica" by Thomas Aquinas says that there is a (single) ever-pressing mind in which there are no unrealized potencies, otherwise it would not be all-knowing and not perfect, not only does the essence coincides with the existence in it, or rather even the existence and its essence, it is also a pure act, which is the cause of all things (ST I. 79.2). In the universal hierarchy it is followed by the angelic mind, which "is always relevant in relation to the things that it thinks of because of its proximity to the first mind" (ST I.79. 2). And finally, the last, the lowest and most distant from the perfection position is the human mind, which is potential in relation to everything intelligible.

Naturally, this entire hierarchy exists and is supported by only one reason: everything that exists is existing because of its connection with the universally existing, it draws its being and finds its main goal. Whatever happens in the world, according to the Medieval Reason, occurs solely by involvement and the higher it is, the more perfect the action is. Neretina very accurately noticed this feature of medieval culture, indicating at the same time a certain tragedy of the age: "True uncreated existence (God) was one thing, and the created thing did not merge with Him, but received communion with Him - this eternal not-before-connectedness gave the era a special tragedy, which is conventionally called the Middle Ages" [18]. This, by the way, is one of the essential differences between the Middle Ages and antiquity: the antiquity is looking for mergers, the Middle Ages - the sacrament. Last but not least, this is why the teachings of Averroes regarding a single intellect, followed by Siger of Brabant, Boetius of Dacia and others, were rejected. The Arabic thinker, relying on the legacy of Aristotle, primarily on the treatise "On the Soul", argued that there is a single world mind (intellect), and individual human intellects are world particles. After death, they merge with this single intellect and cease to exist as independent substances, which naturally went against the Christian teaching about personal (individual) immortality of the soul and salvation. Actually, therefore, the best representatives of scholasticism, including Thomas Aquinas, who dedicated a special treatise to refute mono-intellectualism, opposed the teachings of Averroes. 
So, the medieval mind knows the universe, in which (beyond) the God-Logos (Trinity) is at the top of the hierarchy, causing not only rational activity, but also the very being of all beings. Not only action, but also being is possible in this world solely by participation: the hierarchy of entities is determined by the hierarchy of existence. Analyzing the philosophy of Thomas Aquinas, Étienne Gilson, one of the best experts on the philosophy of Aquinas, gave a very good hermeneutics of this maxim: "Every entity, not being an act of existence, exists because of it and consists in it as its self-determination. Outside of the pure Act of being, nothing can exist in any other way than as this or that concrete existence. Consequently, it is the hierarchy of acts of existence that substantiates and regulates the hierarchy of entities, each of which expresses only the intensity of a certain act of existence" [19]. The nature and cause of the human mind (man as such) indicates pure being, transcendent to all created things: the earthly mind is the result of the existence of the Divine mind. The nature of the classical mind is deeply ontological - rationality does not appear as the adequacy of the conventionally established norms (which is characteristic for the modern mind), or rather, this is not the ultimate level of legitimation, but these norms themselves have a transcendental rationale.

Thus, it can be stated: first, the ontologism of the foundations of the pre-modern mind; secondly, the basis of the classical mind is the Divine Mind - the highest level of the hierarchy of beings (being itself); thirdly, thinking is an "attribute" of being, and not a function of the subject.

\section{Hierarchism (Subordinationism) of the classical mind}

The hierarchism of the pre-modern mind is well known and has been repeatedly analyzed in philosophical and theological literature. As a proof, one can simply turn to the works of Plotinus, Pseudo-Dionysius or John of the Ladder. The hierarchical structure can be easily found in the internal processes of thinking, for example, from sensory seizure through a rational movement to intelligent contemplation, in which the latter is incomparably higher in the general hierarchy. In Platos "Republic" Socrates, after a long discussion, summarizes it as follows: "... at the highest level is mind, on the second - sanity, third place one must give to faith, and the last is likeness, arrange them accordingly, considering that the more this state is participial to the truth and the more reliability it has" [20, p.249]. You can see it in the structure of being itself, which is a system with a clear subordination, built depending on the intensity (proximity) of higher being. "And the aesthetic consciousness and its subject," Losev writes, "are hierarchical, ranging from eternal, immovable and self-identical entities, which are principles and ideas, and ending with the physical, bodily world. Higher here is a pattern for the lower and a condition of possibility for the lower [5, p. 276]. And Gilson, when analyzing the philosophy of Thomas Aquinas, and the medieval worldview in general, wrote that the thinkers of this period were clearly aware of the dependence of any essence on the act of existence, which is the cause of its (essence) existence. Accordingly, the hierarchy of entities is a derivative of the hierarchy of existence that is showing the degree of closeness to the pure act of existence, which of course was God in medieval discourse. All this does not cause any doubt and, to a large extent, this is what distinguishes the classical mind from the modern one. The modern mind is not aware of the hierarchy of entities, and every other hierarchy that it perceives has completely different foundations. 
However, the transformation process that led to the emergence of a new form of mind and culture did not occur simultaneously, and all of its prerequisites are not only in the modern discourse. Another representative of French neo-Thomism, a deep connoisseur of Aquinas philosophy, Jacques Maritain in his work "Saint Thomas, Apostle of modernity" is inclined to blame philosophy of the $16^{\text {th }}$ century and especially Descartes for "treason of reason for its highest purpose" without noticing the symbolism of the name of his own work. He believed that it was then when "...the internal hierarchy of the virtues of reason collapsed, philosophy separated from theology in order to claim the title of higher science, and the mathematical study of the sensual world and its phenomena began to crowd metaphysics, the human mind began to talk about its independence in relation to God and to being..." [21]. However, it is problematic to categorically agree with such conclusions today. If the destruction of the hierarchy can be viewed as a condition for the emergence of new historical conditions, later called Modernity, then ignoring the mental revolution that took place in scholastic philosophy, which, in the end, led to this destruction, looks today completely unjustified. It was within the framework of high scholasticism where a new gnoseological approach to creation has been formulated and the result of which such a reality as "nature" ${ }^{16}$ was discovered, mind gained the opportunity to look at the world as a picture (using Heideggerian terminology), which resulted in the discovery of an interaction (cognition) method with the surrounding reality and adequate to the new realities.

Throughout the Middle Ages, the debate about the nature of universals did not abate; it can be schematically represented as a continuation of the struggle of Aristotelism against Platonism, in the end of which the peripatetics won.

For the Platonic tradition, the process of knowledge is associated with the contemplation of the world of ideas that are substantial in nature. Sensuality can add nothing to this knowledge, and the material world itself appears as contingent and accidental. This maxim of the ancient worldview is perfectly reflected in the work of st. Augustine: "All that bodily senses achieve, that they call sensual, never cease to change. Whether hair grows on our head, the body ages or blooms with youth, this happens in constant becoming, which is never interrupted. But that which is not, cannot be comprehended. Indeed, to comprehend means to understand scientifically, but one cannot understand something which does not cease to change. Therefore, one cannot hope that bodily senses will deliver us the truth in its purity" (cit. to: [22, p. 319]). Matthew of Aqua Sparta concisely formulated the main ethos of this approach, indicating that not things, but ideas are the cause of our knowledge, and if God had captured the form of ideas in our mind, as he did in the case of angels, we would know things as we know now.

Representatives of the same tradition, however, in this matter, already following Plotinus more, were forced to recognize the fundamental unknowability of God. As Plotinus once wrote about the One, showing that the maximum on which the human mind can count is to know that it is not the One, and not what it is. Similarly, representatives of apathic theology denied the possibility of obtaining any positive knowledge about God.

It would seem that this approach fits perfectly into the Christian worldview and is not only based on the ancient tradition, but also on the Holy Scripture, and therefore should not be revised. However, during the period of scholasticism, the opposite approach became the main one, within the framework of which the world of new meanings was born.

${ }^{16}$ It is very useful in this context the work of Anatoly Akhutin dedicated to the genesis of a contemporary understanding of "nature" and its difference from the ancient "physis" in this context. See more: [23]. 
Paradoxically, it is also completely orthodox and no less grounded from the point of view of the Scripture than Platonic-Augustinian is. On the one hand, it can be described as a struggle for the recognition of the value of creation ${ }^{17}$ and, in this case, st. Francis' "Little Flowers" or Aquinas' "Summa Theologica" personify one semantic field: creation is the work of God and therefore is not something that should be avoided. On the other hand, to present it as an attempt of seeking hearts to know the Lord at least by analogy, and therefore the evidence of the existence of God at this time became almost an independent genre.

Albertus Magnus, Thomas Aquinas, Duns Scotus, William of Ockham, while developing a new methodology, discover the heuristic character of sensory knowledge. As Gilson notes in "The Spirit of Medieval Philosophy", after realizing the danger of skepticism emanating from the Platonic concept of knowledge, medieval thought "had nothing left but to rehabilitate the sensual order; this is exactly what was to be done first by St. Thomas Aquinas, then by Duns Scot" [22, p. 324]. Aquinas indicates that the human soul occupies the lowest place among intelligent substances and, like angels, does not possess knowledge of truth by nature, and is therefore capable of knowing only on the basis of private things, through feelings ${ }^{18}$. Here's what Swiezawski writes about the philosophy of St. Thomas: "Sensual knowledge here on earth, in our earthly conditions, determines mental knowledge" [24].

Aquinas asks a question about the connection of the eternal and the transient in our knowledge and responds as follows: "So these two kinds, namely the eternal and the transitory, are connected with our knowledge in such a way that each of them serves as a means for knowing the other. Thus, by reasoning, from knowledge of the transient we arrive at the knowledge of the eternal, for, according to the apostle, "the invisible through the viewing of creations is visible" (Romans 1:20) [17, p. 109]. Basing on the canonical text of Scripture, Thomas Aquinas substantiates the possibility of knowing God through His creations, thus giving the creation a new unprecedented status of the apodictic element of God-knowledge. As Frederick Copleston notes: knowledge becomes anticipation of the vision of God in heaven. From this principle there is only one step to the modern natural science: it is necessary to stop the transcendental level, giving natural knowledge an independent status, and the mind will acquire a new (modern) form that it can apply to the new reality - nature ${ }^{19}$. Rudolf Steiner in his lectures on tomism, appreciating the great

17 The disciple of Gilson and the scientific director Karol Wojtyła, the recognized expert on the philosophy of Thomas Aquinas Stefan Swiezawski noted that Aquinas did enough to defeat sacralism, according to which prayer, service, fasting, etc. has a higher status than ordinary work. "...Each question is sacred in its own way - sacredly everything, wrote Swiezawski, Analyzing the philosophy of St. Thomas. - There are no divisions into sacred and non-sacred. Everything is sacred, and this is the true position of true sacralism. Recall here the words of St. Paul: "So, whether you eat, drink, or whatever you do, do everything to the glory of God" (1 Cor. 10.31) [24].

${ }^{18}$ In this question, and especially regarding the distinction between human and Divine knowledge, there is one interesting and one of the most in-depth studies on the philosophy of Thomas Aquinas, which came out recently, which belongs to the American researcher Eleonore Stump [25].

${ }^{19}$ Describing the process of overcoming Platonic skepticism undertaken by the great scholastics, Gilson wrote: "The only way out of the difficulty lies, therefore, in recognizing: there is empirical certainty based on inference with a stress put on experience. Undoubtedly, the induction of patterns from experience will not lead us to absolutely necessary conclusions: there is no contradiction in the fact that things can be generated in a different way than they are actually produced. But the knowledge that we have about their laws will not be less reliable and infallible because it relies on the stability and necessity of the natures themselves. The great principle, which guarantees the value of experienced knowledge, says that everything 
merit of this tradition in opposition to nominalism, with which he associated the regress of the West, nevertheless said: "The problem that was previously solved by clairvoyance, by means of supersensory perceptions, has now descended into the sphere of thought, into the sphere of activity of the mind. This is the essence of the philosophy of Albert the Great and the philosophy of Thomas Aquinas..." [26].

Franciscan Duns Scotus developed in parallel to Dominican way and came to even more radical conclusions. Starting from the same passage from the Epistle to the Romans of Saint Paul and relying on the Augustinian legacy, Duns Scotus insists that invisible ideas are learned on the basis of creations, respectively, and their cognition (of creations) is of decisive importance. By virtue of a person's lack of the ability to know the truth in itself, he must constantly resort to the help of reason in order to find it. This is how the methodology looks like according to Duns Scotus: “...the human wanderer contemplates the essence of the stone, which for the divine mind is incommensurable and eternal, but he does not see it as eternal and incommensurable, [what it is] in relation to the divine mind, because it does not see its relationship to the divine mind, by virtue of which it is immutable; and he [a person] sees in this object the truth of an object and all that it contains virtually, through a rational study conducted in relation to this object» [2, p. 371]. And in the treatise "On the Knowability of God," he deciphers how this knowledge should be carried out: "The philosopher in Book III about the Soul says:" Images for the mind are perceived as feelings ". But the feeling feels nothing but the sensed; therefore, the mind does not know anything, besides, the images of which it can acquire through feelings» [2, p. 399].

William of Ockham on this matter has advanced even further, he is convinced, as indeed many thinkers before him, that only universals one can know; only he refuses them of any substantiality. The British thinker in his treatise "On Universals" explicitly writes that "a universal is a spoken word" [27, p. 119], and in the treatise "The fact that a universal is not a thing outside the soul" substantiates the position that "no universal is any substance that exists outside the soul..." [27, p. 119]. It follows from this that universals (ideas) have no substantiveness, and therefore no independent existence, independent from the knowing subject. On the contrary, the universal is a product of abstraction, the selection of quidditas, which produces the human mind, and this is where their (universals) universality lies. "There are no such objects as" man in general "or" humanity, "writes medieval philosopher and translator of the works of the English Franciscan into Russian, A. Appolonov, concerning U. Ockham's philosophy, - the general is" mental image "(fictum) or" act of thinking "(actus intelligendi) and does not exist outside of human consciousness" [27, p.XV]. Universals are not separate substances of the world of ideas, but derivatives of human thinking. In the same treatise, Ockham writes: "...the statement exists only in the mind or in written or spoken words. But this is not a private substance. So it is clear that no statement can be made up of substances; but the statement is composed of universals; therefore, universals are not substances in any way possible" [27, p. 123]. Thus, a completely logical connection is built. Universals are not substances, but only a word, a product of abstraction, material for "extracting" quidditas, getting this extract, which provides an empirical world, cognizable by sensuality, respectively, to find

that happens regularly, due to some reason that does not act freely, is a natural consequence of this reason. 'Natural' means: not appropriate, but necessary. Therefore, the knowledge of nature, which we are able to acquire through experience, has the necessary character" [22, p. 331]. 
the truth, you should pay maximum attention to empirical studies that form the basis of genuine knowledge.

An analysis of the texts of representatives of high scholasticism shows that it was during this period, on the one hand, that a new region of reality was discovered and substantiated - "nature", which was initially used exclusively for orthodox purposes of Godknowledge; on the other hand, a new type of mind was formed, adequate to this dimension of reality, which, after detranscendence, has been carried out in the philosophy of New Time, will become an independent system-forming entity ${ }^{20}$.

\section{The transcendence of the foundations of the classic mind}

Proceeding from the fact that for the classical mind the intellect is not a unique result of evolution which characterizes the crown of its development - a man, but an ontological (cosmic) essence, manifested in the human race with the least intensity, its bases are of transcendental nature. Appealing to various classical texts, it is not difficult to show that the origins of the pre-modern mind are transcendental (in the pre-Kantian sense of the term). The individual, potential human mind is able to act only because there is a universal actual mind, which does not only give being to the private minds but is also a rule-maker for them and is itself nothing more than a manifestation of the Good (Plato), an emanation of the One (Plotinus), a manifestation of God (Christian philosophy).

This tradition can be traced from Plato, who, for example, in "Phaedo" considers what makes beautiful beautiful, makes reasonable reasonable, etc. "Look, what will come next," said Socrates, "will it seem so to you, like to me? It seems to me that if there is something beautiful besides beautiful in itself, then it is beautiful for nothing but its participation in that beautiful. I say the same about everything. Do you agree with this reason? "I agree", he answered, "Plato writes [28, p. 170-171]. This is just a sample of the study by the ancient Greek philosopher of his main concept - the theory of the true world of ideas. But at the same time, it is the legitimization of the maxim, which will become the commonplace of all the predominant philosophies about the transcendental dimension as the true cause of the immanent world.

From this point of view it is quite logical that the closer human thinking (action) is to the divine, the more perfect it is. This type of transcendentalism is well noticed by A. Losev. Analyzing the philosophy of Aristotle, the Russian-Soviet thinker pointed out the apodictic connection of the individual mind and the divine: "But if this is so, then the potential presence of mind in a person must be required to recognize the existence of the mind as a whole, regardless of man, mind as such. And if the mind contains only potentially in a person, but actually if it manifests itself and doesn't also, then there is also a mind that is always relevant, infinitely relevant" [4, p. 44]. The meaning of what has been said is quite clear and does not require additional comments. It is only worth noting that this thought of Aristotle will be a very popular Christian philosophy and especially scholasticism.

Plotinus in his "Enneads" repeatedly illustrates the same thought about the transcendental basis of the functioning of individual minds. The extract from the second treatise "On the birth of being" VI "Ennead" is as follows: "Mind is beyond [private] minds, it directs individual minds, it is their strength [= opportunity], it possesses them in their

${ }^{20}$ In this regard, see also Piama Gaydenko's study on the influence of medieval nominalism on the development of the science of the New Age [29]. 
universality. And, again, all minds in their partialness have a universal Mind, just as private knowledge contains knowledge [as such ${ }^{21}$ ]" [30, p. 145]. Simply put: the human mind is the weak counterpart of the Mind of the Divine, that is acting as a transcendental condition for the action of private minds.

At the same time, the concept of enlightening the individual mind with the divine light, which Plotinus ${ }^{22}$ also developed, became an integral part of the Christian doctrine of rational action and the possibility of knowledge. Already St. Augustine in his "Confession", developing this Plato's idea, wrote: "if we both see that what you say is true, and both see that what I say is true, then where, say, please, do we see it? Of course, neither I am in you nor you are in me, but both are in that unchanging Truth, which is higher than our mind" [31, p.212]. Although the doctrine of the independent existence of ideas was not always accepted in the period of the Middle Ages, nonetheless, knowledge and thinking as a process completely imbued with otherworldly light was shared by almost all thinkers. Thomas Aquinas argued that our intellect is capable of action only because of the penetration of mental light from God. "In fact," writes Aquinas, "the very mental light that is in us is nothing more than a participial likeness of uncreated light, which contains eternal types. In this regard, we read [in Scripture]: "Many say:" Who will show us the good? ". And the psalmist answers: "Reveal to us the light of Your Face, Lord!" (Psalm 4: 7), which, in essence, means: we know everything through the divine light imprinted on us ${ }^{23}$ " [17, p. 166]. British connoisseur of heritage of St. Thomas, Frederick Copleston summarizes the thoughts of the great scholastic as follows: "When this (understanding. $-L . V$.) is attributed to God, it is thus stated that there is perfection in God that the human mind is like and not like at the same time. And since this perfection in God is the original source and the highest model for every created mind, this word is metaphysically attributed to God primarily" [32, p. 134]. In order to think and, in general, act rationally, the upper light must appear in the human mind and the potential mind must be enlightened by the mind which is eternally relevant.

Although another representative of high scholasticism, Duns Scotus did not always agree with his senior colleague, there is unity between them on this issue. So in a treatise with the symbolic title "On the knowledge of a human wanderer and the illumination of it with an uncreated light" he writes: "So now everyone agrees that it is true that we learn in the light of the acting mind, not formally though, but effectively; it means that it is also true about us about what we cognize in uncreated light, which contributes to the acting mind, because, as it contributes to our act of knowledge, it has a meaning of light, as does the acting mind; and it is more correct to say about us that we cognize in an uncreated light rather than [to say that we know] in the light of the acting mind, since the first and higher cause has a stronger effect than the immediate cause. And thus, we see the genuine

${ }^{21}$ And in the treatise "On the mind, ideas and existence" of the fifth "Ennead" Plotinus writes: "Beauty arises in the soul through reason. Then: what is that which the mind gives to the soul? With necessity Mind, but not the mind that is sometimes clever, and sometimes stupid, but the true Mind" [14, p. 262].

${ }^{22}$ Here is what Plotinus writes about this in the treatise "On Cognitive Hypostases and what is on the other side": "So, the mind sees the light with light not through anything else. Light sees a different light and, therefore, the light sees itself. This light shines in the soul, enlightening it, making it intelligent, that is, likening itself to the mountain light. If now you present [the light in your soul] as a trace of light coming into the soul, and even more beautiful, great and pure, then perhaps you will come close to the nature of Mind and intelligible "(En V.3.8). See also En V.3.17.

${ }_{23}$ There are many of such discourses in "Summa theologica". For example, see ST I. 87.1; ST I. 89. 2. 
truth in the uncreated truth, which is Light" [2, p. 369], and a few pages earlier, while leading the dialogue, he insists: "The last thing I ask, considering this problem of knowability, is whether the mind of a wandering person can naturally come to know any authentic and genuine truth without the help of special enlightenment from uncreated light. I prove that he can't" [2, p. 337].

Therefore, it can be seen that the search for the foundations of the classical mind leads to otherworldly dimensions, but its very nature and effectiveness are unthinkable without transcendence, which gives energy to it (in the Aristotelian sense) and beingness.

This definition concerns issues that go far beyond epistemology: an aspiration towards the highest goal can be traced in any process from movement to goal-setting. From ancient times this phenomenon is known as entelechy. The most classic description of this process is considered to be a fragment from the seventh chapter of the book XII of Aristotle's "Metaphysics". In this part, Stagirus justifies the nature of motion, pointing to the need to allow the existence of a prime mover (the divine mind), so as not to fall into the regression of evil infinity, which itself is eternally motionless, but is the cause of motion. Further Aristotle wonders about how everything is set in motion. The answer given by the Greek thinker became the cornerstone for the whole Western civilization: "And the object of desire and the object of thought move in this way; they move without being moved" (1072a) [11, p.362]. The motionless prime mover is so beautiful that the whole creation (using Christian vocabulary) clings to it with its whole nature and wants to merge with it in a burst of unified ecstasy, creating movement in the world and acquiring, thus, the ultimate goal of desire. ${ }^{24}$ The soul is capable of any act only because it has the highest guideline (ideal) of its action, which is a necessary condition for any will (goal-setting). The bases of any action are of transcendental nature.

The idea of entelechy, as an organizing principle of being, has perfectly rooted on Christian soil, both in the East and in the West of the Empire. St. Augustine begins with these words his "Confession": “...You have made us to Yourself, and our Hearts are Restless Until They Rest in You" 25 [31, p. 5]. And almost one and a half millennia later, Silouan of Athos proclaimed the same maxim: "... For the soul you need the Lord and the grace of the Holy Spirit, without which the soul is dead. As the sun warms and gives life to wild flowers and they are drawn to him, so the soul who loves God, draws to Him and bliss in Him..." [33]. Thus, on the one hand, entelechy acts as a principle that gives energy to anything, on the other hand, due to the existential dependence of being on the root cause of being, it is the organizing principle of the whole hierarchy of being.

${ }^{24}$ It should be said that although Aristotle gave the most universal definition of entelechy, the intuition and phenomenology of this process is already present in the texts of Plato. In the "Republic", the founder of the Academy writes: "So, this is what I see: in what is knowable, the idea of good is the limit, and it is difficult to distinguish, but as soon as you discern it the conclusion suggests itself that it is the reason to all right and beautiful. In the realm of the visible, it begets the light and its ruler, and in the realm of the intelligible, it itself is the ruler, on which truth and understanding depend, and anyone who wants to act consciously in both private and public life should look at it" [20, with. 253]. See also [20, p. 233].

$25 \mathrm{Sim}$. to the philosophy of Plotinus, for whom entelechy is perhaps the main system-forming principle, and the "Enneads" themselves can be viewed as continuous melancholy and prayer to the One - the only thing that interests the Alexandrian philosopher ultimately is a transition from himself to Him, as an image to a primordial character, thus completing the path (En VI. 9. 11). In the Fifth Ennead, Plotinus writes: "[Not a man only, but] all things are movedand move to Him [to the Good] by virtue of natural necessity, foreseeing [an inner sense] that they cannot be without Him" [14, p. 158]. See also En VI. 2. 11. 
Basing on the analysis of this principle, it is necessary to note its relevance throughout the history of the development of the West. After the transcendental dimension was finally docked (German classical philosophy), the principle of entelechy was not forced out of history. Modern mind was unable (did not want?) to overcome this rudiment. The only thing is that the field of its implementation has finally moved to the immanent space of social practice. This process can be easily found in the principles of the functioning of the limit (for the modern mind) dimension - the hierarchy of collective subjects (states).

Thus, it can be stated that the necessary condition for the functioning of the classical mind is the transcendent as such, which is generally the primary cause of everything immanent. At the same time, the doctrine of entelechy, despite its ancient origins, is in demand throughout the history of the West and today is representing the system-forming principle of the organization of social space.

Summarizing the results of this study, one should focus on the following. First, the most emblematic characteristics of the classical mind, which constitute its nature and form, are ontological, transcendent, and hierarchical. Each of these attributes fundamentally distinguishes the classical mind from the modern one. Secondly, within the framework of the classical mind, certain principles were formulated (dichotomous division of knowledge into rational and rational, entelechy, ratiocentricity, etc.), which became archetypical for Western rationality as such, some of which, after the secularization of medieval culture, became the principle of organization for secular social reality. Thirdly, in times of high scholasticism, intellectual basis was prepared for the destruction of the hierarchy of entities, which led to the emergence of a new subject of research - an empirical reality that required a new type of rationality. In the end, this led to the emergence of a new social reality as such, later called the Modernity.

\section{References}

1. Thomas Aquinas (2015), De unitate intellectus contra averroistas, LENAND Publ., Moscow. (In Russian)

2. Duns Scotus (2001), Collected Works, Frantsiskantsev Publ., Moscow, 584 p. (In Russian)

3. Cassin, B. (ed.) (2011), Dictionary of Untranslatables: A Philosophical Lexicon, vol. 2, Duh i Litera Publ., Kyiv. (In Ukrainian)

4. Losev, A.F. (1975), History of the Ancient aestethics. Aristotle and the late Classics, Iskusstvo Publ., Moscow, 672 p. (In Russian)

5. Losev, A. F. (1994), History of the Ancient aestethics. Sophists. Socrates. Plato, Ladomir Publ., Moscow, 714 p. (In Russian)

6. Leonov, V. Concepts "Mind", "Intellect", "Reason" in the tradition of Church Fathers, available at: https:// azbyka.ru/ponyatiya-um-razum-rassudok-v-svyatootecheskoj-tradicii (accessed: 18.03.2018). (In Russian)

7. Averintsev, S. S. (1979), Neoplatonism in front of Platonic critique of the myth-poetry thinking, in Platon i ego epokha, Nauka Publ., Moscow, pp. 83-97. (In Russian)

8. Pre-Socratics, trans. from Ancient greek by A. Makovel'skii, pt. 1 (Eleate period), available at: http:// filosof.historic.ru/books/item/f00/s00/z0000120/st013.shtml (accessed: 18.03.2018). (In Russian)

9. Plato (2014), Collected works, vol. VI, Liteo Publ., St. Petersburg. (In Russian)

10. Borodai, T. Yu. (2008), The birth of philosophical concepts. God and matter in the dialogues of Plato, Savin Publisher, Moscow, 283 p. (In Russian)

11. Aristotle (2016), Metaphysics, «E» Publ., Moscow. (In Russian)

12. Heidegger, M. (1991), On the essense of truth, in Heidegger, M. (ed.), Razgovor na proselochnoi doroge, Vysshaia shkola Publ., Moscow, pp. 8-27. (In Russian)

13. Heidegger, M. (1993), Plato's teaching on truth, in Heidegger, M., Vremya i bytie: Stat'i i vystupleniya, Respublika Publ., Moscow, pp. 345-360. (In Russian) 
14. Plotinus (2016a), The fifth ennead, Oleg Abyshko Publ., St. Petersburg, 320 p. (In Russian)

15. Losev, A. F. (1980), History of the Ancient aestethics. Late Hellenism, Iskusstvo Publ., Moscow, 766 p. (In Russian)

16. Proclus, Elements of Theology, available at: http://www.odinblago.ru/filosofiya/losev/aflosev_istoriya_antichno/prokl_pervoosnovi_/(accessed: 18.03.2018). (In Russian)

17. Thomas Aquinas (2005), Summa Theologiae, Nika-Tsentr Publ., Moscow, 576 p. (In Russian)

18. Neretina, S.S., Capabilities of understanding, available at: http://krotov.info/acts/04/avgustin/ustin_001.htm (accessed: 18.03.2018). (In Russian)

19. Gilson, E., Thomism, available at: http://krotov.info/history/12/3/gilson0.html (accessed: 18.03.2018). (In Russian)

20. Plato (2013), The State, Kniga po trebovaniiu Publ., Moscow. (In Russian)

21. Maritain, J., Saint Thomas, Apostle of our days, available at: http://diakonia.narod.ru/lib/foma. htm??4.4 (accessed: 18.03.2018). (In Russian)

22. Gilson, E. (2011), The Spirit of Mediaeval Philosophy, Institut filosofii, teologii i istorii sv. Fomy Publ., Moscow, 560 p. (In Russian)

23. Akhutin, A. V. (1988), Definition of Nature in Antiquity and Modernity. "Physis" and "Natura", Nauka Publ., Moscow, 208 p. (In Russian)

24. Svezhavski, S., Saint Thomas reconverted, available at: http://psylib.ukrweb.net/books/swezh01/ txt15.htm (accessed: 18.03.2018). (In Russian)

25. Stamp, E. (2013), Aquinas, Iazyki slavianskoi kul'tury Publ., Moscow, 353 p. (In Russian)

26. Steiner, R., Philosophy of Thomas Aquinas, available at: http://bdn-steiner.ru/modules. php? name=Steiner\&go=page\&pid=74 (accessed: 18.03.2018). (In Russian)

27. Ockham, W. (2015), Collected works, Lenand Publ., Moscow, 232 p. (In Russian)

28. Plato (2016), Dialogues, RIPOL klassik Publ., Moscow, 576 p. (In Russian)

29. Gaidenko, P.P., Medieval nominalism and the genesis of a new European mentality, available at: http:// vphil.ru/index.php?option=com_content\&task=view\&id=908 (accessed: 18.03.2018). (In Russian)

30. Plotinus (2016b), The sixth ennead, Oleg Abyshko Publ., St. Petersburg, 478 p. (In Russian)

31. Sanctus Augustine (2013), Confessions, Nauka Publ., St. Petersburg, 373 p. (In Russian)

32. Copleston, F. Ch. (1999), Aquinas: An Introduction to the Life and Work of the Great Medieval Thinker, Vestkom Publ., Moscow, 276 p. (In Russian)

33. Starets Siluan Afonskii, On the Grace, available at: http://afonit.info/biblioteka/nasledie-russkogomonastyrya/starets-siluan-afonskij-o-blagodati (accessed: 18.03.2018). (In Russian)

Received: December 6, 2018

Accepted: June 13, 2019

Author's information:

Viktor S. Levytskyy — PhD in Philosophy; victor2609@ukr.net

\section{Природа и сущностные характеристики классической рациональности}

\section{В. С. Левицкиц̆}

Украинский институт стратегий глобального развития и адаптации, Бельгия, 1040, Брюссель, пл. Робера Шумана, 6

Для цитирования: Levytskyy V.S. Nature and essential characteristics of classical rationality // Becтник Санкт-Петербургского университета. Философия и конфликтология. 2019. Т. 35. Вып. 3. C. 430-446. https://doi.org/10.21638/spbu17.2019.304

$\mathrm{XX}$ столетие прошло под знаком деконструкции классического понимания субстанциональности истории, культуры, разума. Оказалось, что каждая культура имеет свои уникальные мировоззренческие универсалии, был сделан вывод о принципиальном отличии классического и модерного культурных миров, а соответственно и свойствен- 
ных им рациональностей. Если классическая рациональность опиралась на мифологические и религиозные доминанты, то разум эпохи модерна абсолютизировал просвещенческие ценности. В статье предпринимается попытка уточнения существенных черт классического разума и его отличия от современной рациональности, в частности реконструируются место и значение взглядов на трансцендентное в домодерном рациональном дискурсе, подчеркивается значение процессов секуляризации для формирования модерной рациональности. В статье концепция научной рациональности, разработанная В.С. Степиным и получившая заслуженное признание в философии науки, распространяется на более широкий культурный контекст. С точки зрения этой концепции предпринимается попытка охарактеризовать классический разум на основе онтологического, эпистемологического и субъект-объектного критериев. Экспликация сущностных характеристик классического разума имеет эвристичный потенциал при сравнении домодерной и современной рациональности. В частности выделяются и на основе историко-философского материала обосновываются отличительные черты классического (домодерного) разума: его онтологизм - укорененность в бытии, только частично связанном с человеком; иерархизм - зависимость познавательных возможностей от онтологического уровня открывающихся разуму сущностей и трансцендентность - принципиальная непостижимость оснований и «гарантов» разума и мира для самого разума. В рамках классического разума были сформулированы архетипические принципы западной рациональности как таковой, часть которых после секуляризации средневековой культуры стала принципом организации светской социальной действительности, что в конечном итоге повлекло за собой формирование новой социальной реальности - Модерна.

Ключевые слова: разум, рациональность, модерн, онтология, иерархия, трансцендентность.

Статья поступила в редакцию 6 декабря 2018 г;; рекомендована в печать 13 июня 2019 г.

Контактная информация:

Левицкий Виктор Сергеевич - канд. филос. наук; victor2609@ukr.net 